\title{
KEANEKARAGAMAN FUNGI MIKORIZA ARBUSKULAR PADA RHIZOSFER AREAL REVEGETASI LAHAN PASCATAMBANG EMAS PT NATARANG MINING
}

\author{
Diversity of Arbuscular Mycorrhizal Fungi in the Rhizosphere of the Revegetation Area \\ of PT Natarang Mining
}

\section{Siti Tisas Sitra Sanana*, Ceng Asmarahman, Melya Riniarti, Duryat}

Jurusan Kehutanan, Fakultas Pertanian, Universitas Lampung, Jl.Soemantri Brojonegoro No. 1, Gedong Meneng, Bandar Lampung, 35145, Lampung, Indonesia.

*e-mail: sananasitra@gmail.com

Diterima : 26/04/2021, Direvisi : 07/07/2021, Disetujui : 07/07/2021

\begin{abstract}
Identification of local AMF is crucial in accelerating the process of successful revegetation on post-mining land. The research objective was to identify the diversity of AMF species on PT Natarang Mining's post-mining land. Soil sampling using purposive sampling techniques in a non-proportional manner with a plot measuring $20 \mathrm{~m} \times 20 \mathrm{~m}$ determined based on the spread of vegetation growing at the location. Sampling site on revegetation land in 2015 and 2018. The AMF spores were obtained by using a wet filter method and the data obtained were analyzed by descriptive analysis. The results of the study identified that there were 3 genera found, namely Acaulospora sp. Glomus sp and Gigaspora sp. The diversity of FMA species in both locations is classified as moderate. Soil chemical properties correlated with the number and type of arbuscular mycorrhizal spores found at all locations. Further research is needed to clearly identify the species and characteristics of the spores and their application can increase the success of reclamation.
\end{abstract}

Keywords: acaulospora sp; arbuscular mycorrhiza; gigaspora sp; glomus sp; post-mining land;

\begin{abstract}
ABSTRAK
Identifikasi FMA lokal sangat penting dalam mempercepat proses keberhasilan revegetasi pada lahan pascatambang. Tujuan penelitian adalah mengidentifikasi keragaman jenis FMA pada lahan pascatambang PT Natarang Mining. Pengambilan sampel tanah menggunakan teknik purposive sampling secara non proporsional dengan plot berukuran $20 \mathrm{~m}$ x $20 \mathrm{~m}$ yang ditentukan berdasarkan pada sebaran vegetasi yang tumbuh dilokasi. Lokasi pengambilan sampel pada lahan revegetasi tahun 2015 dab 2018. Spora FMA diperoleh menggunakan metode saring basah dan data yang diperoleh dianalisis menggunakan analisis deskriptif. Hasil penelitian telah teridentifikasi terdapat 3 genus yang ditemukan, yaitu Acaulospora sp. Glomus sp dan Gigaspora sp. Keanekaragaman jenis FMA pada kedua lokasi tergolong sedang. Keadaan sifat kimia tanah berkolerasi dengan jumlah dan tipe spora mikoriza
\end{abstract}


arbuscular yang ditemukan pada semua lokasi. Penelitian lebih lanjut diperlukan untuk mengetahui spesies dan karakteristik spora dengan jelas serta dalam pengaplikasiannya mampu meningkatkan keberhasilan reklamasi.

Kata kunci: acaulospora sp; gigaspora sp; glomus sp; lahan pascatambang; mikoriza arbuskular

\section{PENDAHULUAN}

Kegiatan penambangan emas berdampak negatif terhadap lingkungan seperti hilangnya keanekaragaman hayati, meningkatnya erosi, rusaknya habitat satwa liar, berkurangnya areal hutan, menurunkan kesuburan tanah, dan hilangnya vegetasi (Novera, 2008; Pratomo et al., 2018). Masalah yang sering terjadi ialah sulitnya lahan pascatambang ditumbuhi tanaman karena kurangnya kandungan unsur hara hingga berdampak pada kematian pada tanaman (Anggreiny et al., 2017; Juliarti et al., 2020). Dampak tersebut dapat dikurangi dengan kegiatan reklamasi (Szwedzicki, 2001). Upaya yang dapat dilakukan adalah dengan memanfaatkan mikroorganisme potensial tanah yaitu Fungi Mikoriza Arbuskula (FMA) untuk membantu pengembalian kesuburan lahan. Hal ini sesuai dengan penelitian Ekawati et al., (2016) bahwa pemberian mikoriza pada tanah pascatambang nikel berpengaruh nyata terhadap pertumbuhan tanaman Nauclea orientalis, penelitian ini menunjukkan kemampuan tanaman dalam menyerap logam pada tanah pascatambang nikel yang diakumulasi pada jaringan akar dan daun.

Simbiosis mutualisme yang terbentuk antara FMA dengan perakaran tanaman dapat membentuk luas serapan unsur hara yang besar (Karti, 2004; Luthfiana et al., 2020). Pemanfaatan mikoriza di bidang kehutanan dapat meningkatkan pertumbuhan semai tanaman kehutanan sehingga semakin luas diaplikasikan, terutama pada lahan marginal serta meningkatkan ekosistem daratan (Hardiatmi, 2008). Hal ini sejalan dengan pendapat Asmarahman et al., (2018) dimana secara ekologi dan alamiah pemanfaatan FMA potensial lokal lebih diprioritaskan dikarenakan sudah mampu hidup dan beradaptasi dengan kondisi lingkungan tambang tersebut.

Identifikasi FMA lokal sangat penting sebagai sumber inokulan. Sumber inokulan tersebut sebagai mikroba potensial berperan aktif dalam mempercepat proses keberhasilan revegetasi pada lahan pascatambang serta meningkatkan mutu bibit atau kualitas bibit di persemaian pertambangan. Penelitian Tuheteru et al., (2011) membuktikan bahwa penggunaan FMA lokal sangat signifikan dalam memicu pertumbuhan awal tanaman Albizzia saponaria pada lahan pascatambang nikel, adanya korelasi positif antara persentase kolonisasi akar FMA lokal dengan meningkatnya pertumbuhan maupun mutu bibit $A$. saponaria skala pembibitan. Penelitian ini bertujuan untuk mengidentifikasi keragaman jenis FMA pada areal revegetasi lahan pascatambang emas PT Natarang Mining.

\section{METODE}

Penelitian dilaksanakan pada bulan Januari sampai April 2021 menggunakan metode survey dan data yang diperoleh dianalisis secara deskriptif. Metode survey yang diigunakan pada penelitian ini dengan cara mengambil sampel tanah secara langsung dari lapangan. Pengambilan sampel tanah dilakukan pada areal revegetasi pascatambang emas PT Natarang Mining pada jaminan reklamasi tahun 2015 dan 2018. Masing-masing site diambil sebanyak 3 
titik (Gambar 1). Selanjutnya dilakukan pengisolasian jenis FMA yang terdapat di site. Selain itu, untuk data pendukung dilakukannya analisis kimia tanah. Aspek yang dianalisis berupa $\mathrm{pH}$ $\left(\mathrm{H}_{2} \mathrm{O}\right)$, C-Organik, N-Total dan P-Tersedia.

Bahan-bahan yang digunakan dalam penelitian adalah sampel tanah pada areal revegetasi pascatambang emas PT Natarang Mining, larutan melzer's reagent, plastik sampel, kertas label, dan aquades. Alat-alat yang digunakan adalah cangkul, dan spidol. Pada pengamatan di laboratorium mengunakan alat saringan spora yaitu saringan bertingkat berukuran $500 \mu \mathrm{m}, 250 \mu \mathrm{m}, 90 \mu \mathrm{m}, 45 \mu \mathrm{m}$, pinset spora, mikroskop compound dan binokuler, sprayer, kaca preparat, cover glass, petridish, timbangan analitik, buku spora mikoriza, kamera dan gunting.

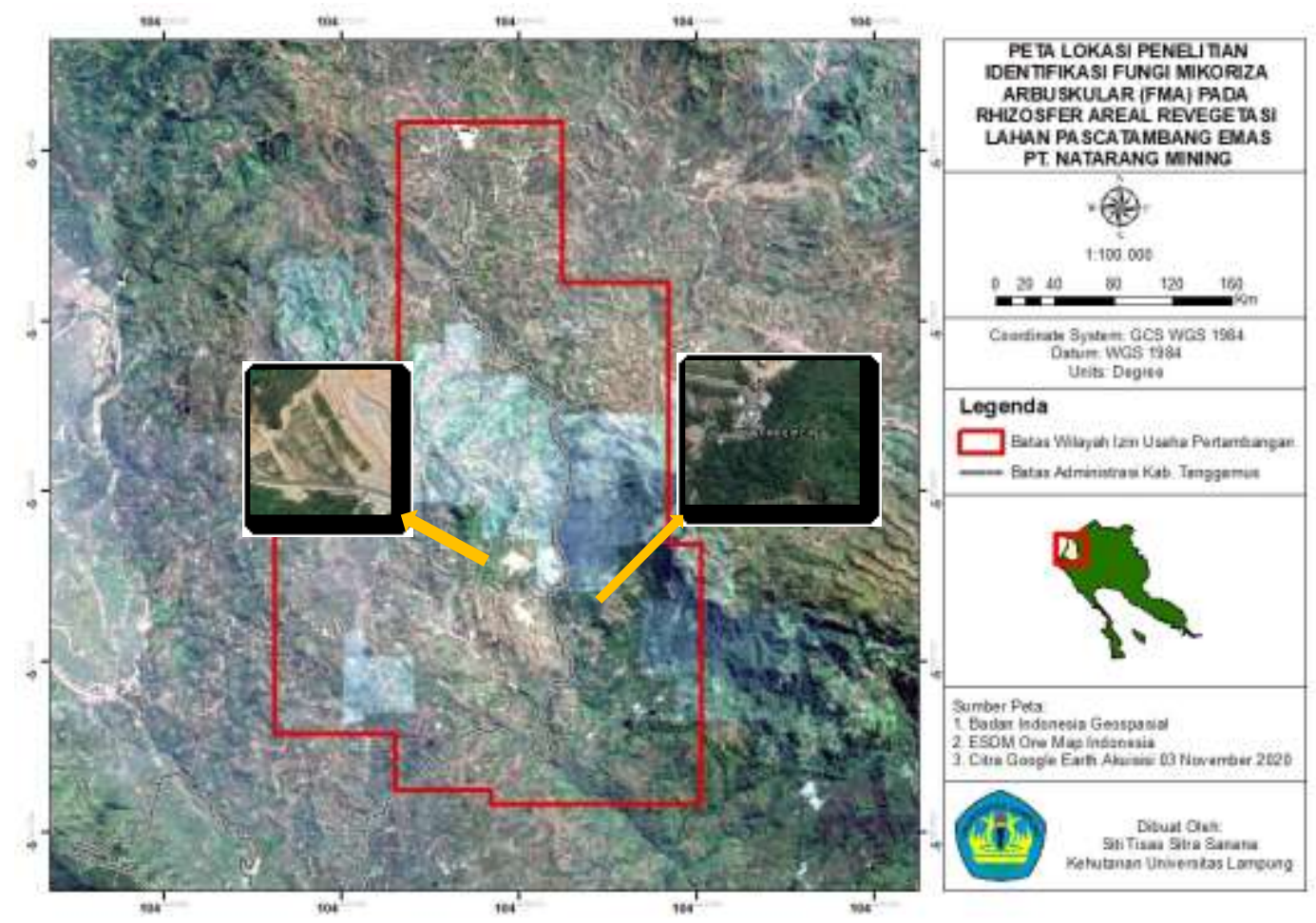

Gambar 1. Lokasi Penelitian.

Figure 1. Research location.

Penentuan titik pengambilan sampel tanah menggunakan teknik purposive sampling secara non proporsional. Teknik tersebut ditentukan berdasarkan kondisi lapangan yang ada yaitu pada sebaran vegetasi yang tumbuh dilokasi (Nusantara et al., 2012). Titik sampel tanah diambil pada kedalaman $0 \mathrm{~cm}-20 \mathrm{~cm}$ dengan 3 kali ulangan pada masing-masing site kemudian dikompositkan sebanyak $2 \mathrm{~kg}$. Sampel tanah dimasukkan ke dalam plastik sampel kemudian diberi keterangan lokasi dan tanggal pengambilan. Pemisahan sampel tanah dari bahan yang tidak penting dan dilanjutkan penimbangan sampel uji tanah sebanyak 50 gr permasing-masing sampel tanah. Isolasi spora dilakukan dengan metode tuang saring basah (Pacioni, 1992) untuk mendapatkan keragaman spora FMA. Isolasi dilakukan sebanyak 5 kali ulangan pada setiap sampel. Identifikasi genus morfologi spora FMA (warna, bentuk, ukuran, hifa attachment dan ornamen spora) dengan pembuatan preparat awetan. Spora ditetesi larutan melzer's regeant 
pada masing-masing genus FMA yang ditemukan. Hasil pengamatan dalam bentuk tabel dianalisis secara deskriptif dengan menyajikan keanekaragaman spora.

\section{HASIL DAN PEMBAHASAN}

\section{A. Kondisi Umum Lokasi}

PT Natarang Mining merupakan perusahaan yang bergerak dibidang pertambangan emas yang terletak di Kabupaten Tanggamus, Provinsi Lampung. Perusahaan tersebut masuk ke dalam joint venture dengan kepemilikan saham $85 \%$ oleh Natarang Offshore Proprietary Limited Company (Pty.Ltd) yang berada di Australia. Kepemilikan 15\% saham dimiliki oleh PMDN yang merupakan perusahaan tambang perak dan emas yang ada di Tanggamus, Provinsi Lampung. Wilayah kontrak karya ini berada di Kawasan Hutan Lindung Register 39 Kota Agung Utara dengan luas 95.685,50 ha.

Luas wilayah ini mengalami beberapa kali penciutan menjadi 10.540 ha berdasarkan Keputusan Menteri Energi dan Sumber Daya Mineral No: 297.K/34.02/DJB/2007. Luasan wilayah tersebut berada pada kawasan hutan lindung seluas 8.626,44 ha (SK Menhut No.586/Menhut-II/2013 dan kawasan Areal Penggunaan Lain (APL) seluas 1.913,56 ha. Lahan dari lokasi tersebut terbagi menjadi dua izin pinjam pakai kawasan hutan (IPPKH) yaitu Blok Way lingo dengan luas 40,05 ha dan Blok Talang Santo seluas 52,5 ha. Proses penambangan secara underground mulai dilakukan pada tahun 2010 di area Way Linggo dan tahun 2014 di area Talang Santo. Pada tahun 2018 PT Natarang Mining mendapatkan persetujuan perubahan metode penambangan menjadi open pit mine (PT Natarang Mining, 2018).

PT Natarang Mining termasuk dalam salah satu dari 13 perusahaan yang diperbolehkan melakukan kegiatan pertambangan di kawasan hutan lindung sampai berakhirnya izin dan perjanjian dimaksud menurut Keputusan Presiden RI No 41 Tahun 2004. Selain itu kegiatan PT Natarang Mining diperbolehkan melakukan pertambangan terbuka di hutan lindung berdasarkan Peraturan Menteri Lingkungan Hidup dan Kehutanan RI Nomor P.50/Menlhk/Setjen/Kum.1/6/2016. Program pokok pascatambang yang akan dilaksanakan meliputi upaya rehabilitasi dan reklamasi. Reklamasi lahan ditujukan untuk memulihkan kondisi lahan sehingga mendekati kondisi sebelum penambangan.

Luas lahan yang digunakan untuk kegiatan tambang seluas $\pm 120,99$ ha. Pada saat ini reklamasi dan revegetasi pada tahap operasi seluas $\pm 48,48$ ha. Pada tahap pascatambang yang akan direklamasi seluas $\pm 34,35$ ha, sehingga reklamasi pascatambang mencapai $100 \%$. Selain perusahaan melakukan reklamasi bentuk lain pada tahap operasi produksi seluas 17,10 Ha dan pada tahap pascatambang seluas 21,05 ha (PT Natarang Mining, 2019). Berdasarkan Addendum Andal, RKL-RPL tahun 2018, lahan pascatambang permukaan akan direklamasi yang dimulai dari penataan lahan. Kondisi yang diharapkan lahan lebih stabil untuk dilakukan revegetasi. Pemasangan corinet dalam penanganan menata lahan dan lereng yang selantjutnya dilakukan hydroseeding.

Hydroseeding merupakan suatu teknologi revegetasi yang berarti campuran antara bibit dan air yang dikombinasikan. Teknik ini menstimulasi perkecambahan lebih cepat, penutupan tanah yang lebih luas, dan mengurangi erosi tanah. Jenis tanaman yang digunakan adalah tanaman pioneer yaitu sengon buto dan sengon laut. Selain itu, tanaman akan diselingi dengan tanaman kayu lokal meliputi cempaka, bayur, medang, trembesi, mindi, sungkai, mahoni, kayu afrika, gmelina (PT Natarang Mining, 2019). 


\section{B. Keanekaragaman Jenis FMA}

Dari kegiatan isolasi dan identifikasi spora FMA pada rhizosfer areal revegetasi pascatambang emas PT Natarang Mining diperoleh 19 jenis spora FMA. Tipe spora yang diperoleh memiliki ciri-ciri bentuk dan warna spora yang berbeda, sehingga didapatkan tiga genus spora FMA yaitu Glomus, Gigaspora, dan Acaulospora (Gambar 2). Jenis Glomus didapatkan sebanyak 6 tipe spora, Gigaspora didapatkan sebanyak 8 tipe spora dan Acaulospora didapatkan sebanyak 5 tipe spora. Keanekaragaman FMA pada lokasi penelitian dapat dilihat dengan adanya perbedaan jumlah populasi genus FMA.

Tabel 1. Indeks keragaman jenis dan dominasi

Table 1. Type diversity and dominance index

\begin{tabular}{rcccc}
\hline No & Tahun Revegetasi & Jumlah Individu & $\mathrm{H}^{\prime}$ & $\mathrm{C}$ \\
\hline 1 & 2018 & 314 & 2,12 & 0,45 \\
2 & 2015 & 257 & 1,57 & 0,30 \\
\hline
\end{tabular}

Keterangan: H' (Indeks Keragaman Jenis), C (Indeks Dominasi)

Perhitungan indeks keragaman Shannon-Wiener, spora FMA yang ditemukan pada sampel tanah tahun reklamasi 2018 dan 2015 memiliki keragaman sebesar $1<2,12<3$ dan $1<1,57<3$. Magurran (2004) menyatakan bahwa nilai $\mathrm{H}^{\prime} \quad 1<\mathrm{H}^{\prime}<3$ menunjukkan bahwa keanekaragaman jenis pada suatu kawasan tergolong sedang. Keberagaman spora mikoriza ditemukan pada areal revegetasi yang memiliki $\mathrm{pH}$ masam yaitu sebesar 4,0-4,5 (Tabel 2) dipengaruhi oleh faktor biotik dan faktor abiotik. Menurut Hajoeningtijas (2009) faktor biotik meliputi interaksi mikroba, spesies fungi, tanaman inang, tipe perakaran pada tanaman inang dan kompetisi antar fungi mikoriza sedangkan faktor abiotik yaitu konsentrasi hara, $\mathrm{pH}$, kadar air, temperatur, pengolahan tanah, dan penggunaan pupuk pestisida. Hasil penelitian ini tidak sejalan dengan penelitian Lee et al., (2009) yang menyatakan bahwa keragaman, kepadatan spora, dan infeksi FMA berkolerasi negatif dengan $\mathrm{pH}$ tanah. Namun hasil penelitian ini sejalan dengan penelitian Yusriadi et al., (2018) yang menunjukkan bahwa tingginya keragaman spora yang ditemukan pada $\mathrm{pH}$ yang bernilai rendah begitupun sebaliknya, hal ini dikarenakan mikoriza bekerja lebih efektif pada tanah yang kekurangan unsur hara dibandingkan pada tanah yang memiliki cukup hara.

Dari nilai indeks dominansi (Tabel 1) tidak ada jenis spora FMA yang dominan. Kisaran indeks dominansi berada pada skala 0 sampai 1 . Perhitungan indeks dominansi yang diperoleh mendekati nilai 1 yaitu sebesar 0,45 dan 0,30 . Hal ini berarti semua jenis endomikoriza yang ditemukan dapat hidup dengan baik pada lokasi penelitian. Jenis spora FMA yang ditemukan dapat berkontribusi dengan besar terhadap ketahanan dan peningkatan pertumbuhan tanaman dalam kegiatan rehabilitasi lahan pascatambang. Adanya perusakan habitat alami seperti pengkonversian lahan, pecemaran kimia dan organik, serta perubahan iklim menjadi faktor utama yang mempengaruhi jumlah organisme, keragaman jenis dan dominansi (Widodo, 2011). Hal ini sesuai dengan penelitian Setiadi (2011) yang menjelaskan bahwa spora mikoriza dengan genus Gigaspora margarita, Acaulospora sp. dan Glomus sp. dapat bertahan hidup pada kondisi lahan pascatambang nikel. 


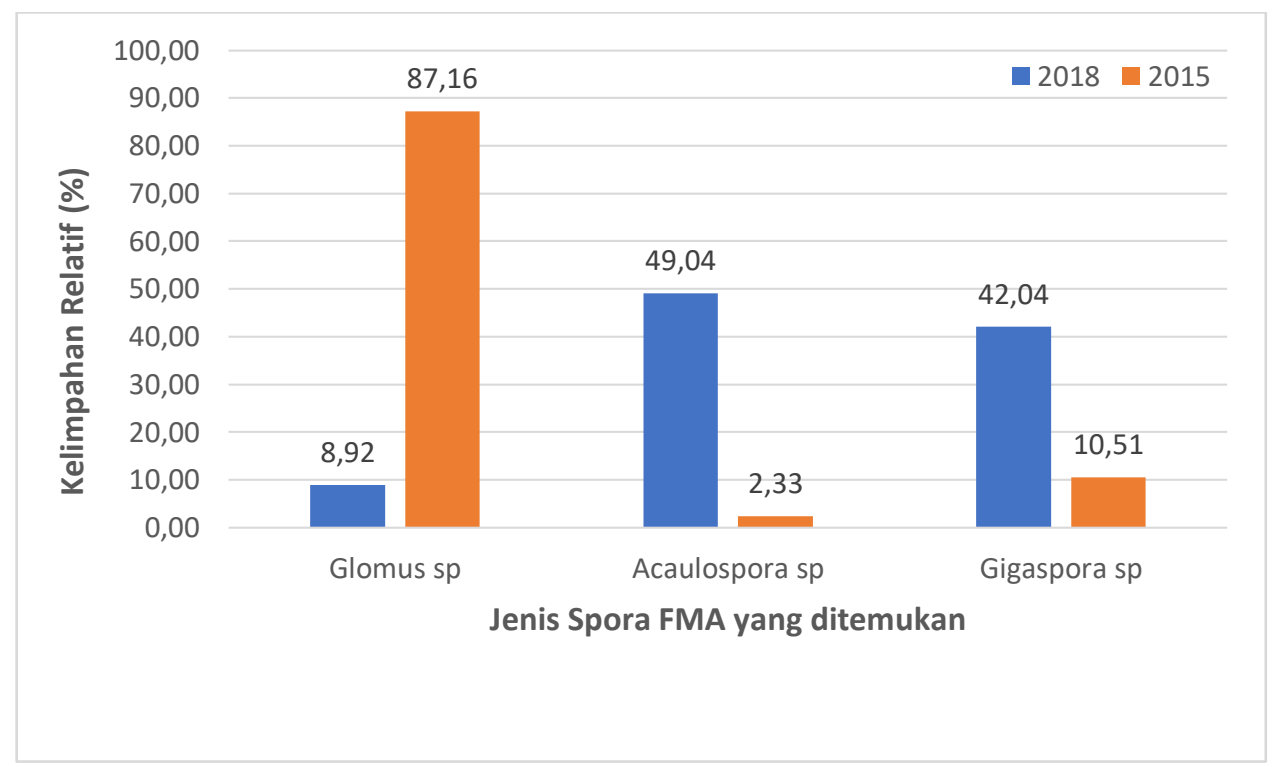

Gambar 2. Kelimpahan relatif.

Figure 2. Relative abundance.

Nilai kelimpahan relatif genus Glomus sp pada lokasi umur tanam tahun 2015 sebesar 87,16\%, Acaulospora sp 2,33\% dan Gigaspora sp 10,51 (Gambar 2). Tingginya nilai kelimpahan genus Glomus disebabkan karena genus ini memiliki penyebaran yang luas (Tarmedi, 2006). Selain itu tanah pada lokasi tersebut bertekstur lempung. Menurut Simangunsong (2006), kondisi tanah yang didominasi oleh fraksi lempung diduga sesuai untuk perkembangan spora Glomus, sementara itu tanah bepasir sesuai untuk perkembangan Gigaspora. Adapun kelimpahan genus Glomus pada tahun tanam 2018 memiliki nilai yang paling sedikit yaitu sebesar 8,92\% (Gambar 2), hal ini diduga tanah dikarenakan pada lokasi tersebut bertekstur pasir. Sementara genus Acaulospora sp dan Gigaspora sp memiliki nilai kelimpahan relatif sebesar 49,04\% dan 42,04\% (Gambar 2).

Kelimpahan spora juga dipengaruhi oleh unsur hara P. Semakin tinggi kandungan unsur $\mathrm{P}$ yang tersedia pada tanah maka kelimpahan spora menurun. Hal ini sesuai dengan Yusriadi et al., (2018) menjelaskan bahwa kandungan unsur hara khususnya unsur $P$ berpengaruh terhadap fungi mikoriza, dimana fungi mikoriza tidak berkembang dengan baik apabila tingkat kesuburan tanah yang baik, terutama dengan kandungan unsur hara $P$ tersedia yang tinggi. Secara umum kemampuan spora FMA untuk beradaptasi dengan kondisi lokal cukup tinggi. Pada kondisi tanah yang berbeda-beda ditemukan juga jumlah populasi FMA yang berbeda. Pada setiap lokasi ditemukan genus FMA seperti Glomus, Acaulospora dan Gigaspora hanya saja tingkat kelimpahan yang membedakan. Menurut Delvian (2003) peningkatan jumlah spora cenderung meningkat seiring berkurangnya jumlah curah hujan, kondisi kelembaban tanah juga dapat mempengaruhi pembentukan perkembangan spora. Pada musim kering spora FMA aktif untuk berkembang membentuk spora, sedangkan pada musim hujan terjadi sebaliknya (Rainiyati, 2007).

Populasi spora FMA lebih banyak ditemukan pada lokasi umur tanam 2018. Semakin lama umur tanam jumlah spora yang ditemukan semakin sedikit begitupun sebaliknya. Widiastuti (2006) menyatakan bahwa umur tanaman sangat mempengaruhi populasi FMA di tanah. Kondisi tersebut disebabkan oleh terjadinya perbaikan kondisi tanah seiring bertambahnya umur tanaman. Sifat fisik tanah dan sifat kimia tanah mengalami perbaikan seiring bertambahnya umur reklamasi lahan (Sofyan et al., 2017). Pada penelitian ini menunjukkan bahwa kondisi tanah dan umur tanaman berpengaruh terhadap kelimpahan spora yang 
ditemukan. Hal ini sesuai dengan penelitian Manaroinsong dan Lolong (2015) bahwa populasi spora mikoriza tertinggi ditemukan pada tanah gambut dengan umur tanam $<5$ tahun yaitu sebanyak 283 spora/100 gr tanah, sedangkan populasi mikoriza terendah ditemukan pada tekstur tanah liat berlempung dengan umur tanam $>10$ tahun sebanyak 175,3 spora/100 gr tanah.

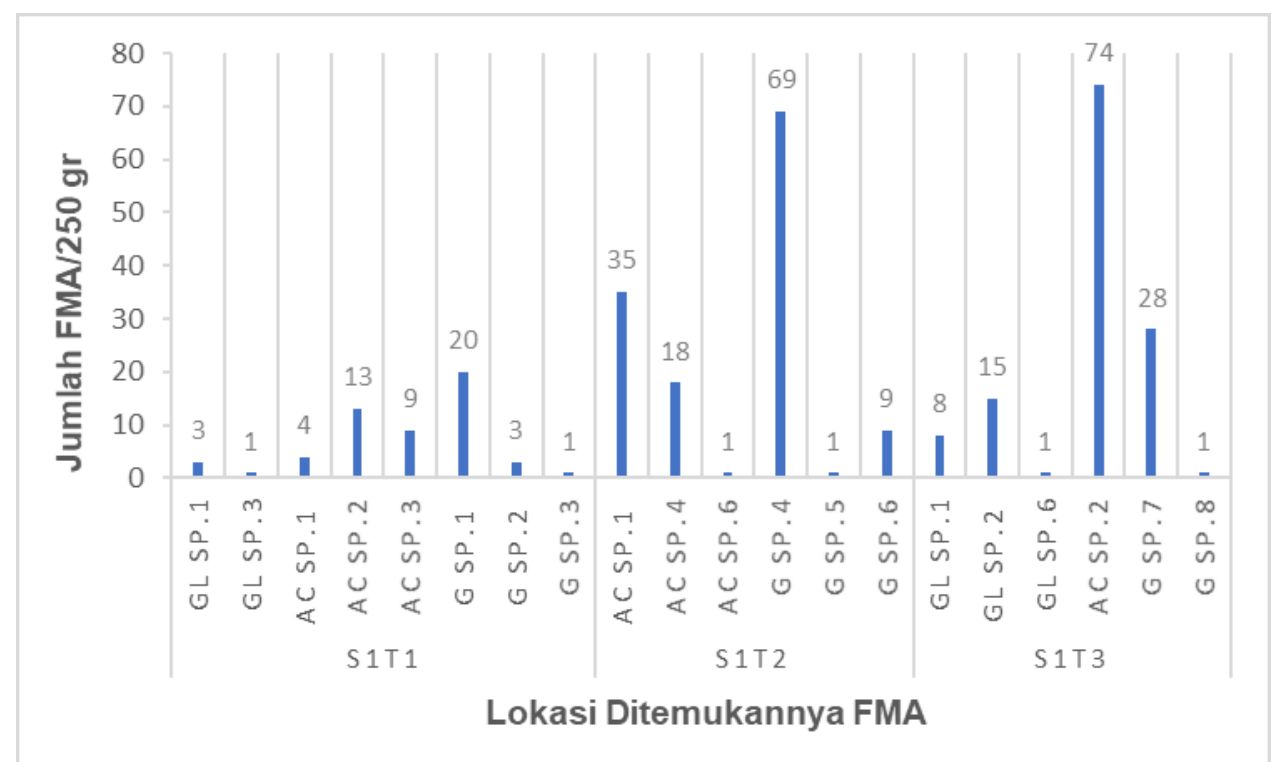

Gambar 3. Jenis-jenis spora yang ditemukan pada lokasi areal revegetasi pascatambang tahun 2018 PT Natarang Mining.

Figure 3. Types of spores found at the site of post-mining revegetation area in 2018 at PT Natarang Mining's.

Keterangan: S1T1 (Site 1 Titik ke-1), S1T2 (Site 1 Titik ke-2), S1T3 (Site 1 Titik ke-3), GI (Glomus), Ac (Acaulospora), G (Gigaspora), dan sp. (Spesies).

Spora pada tempat yang berbeda menhasilkan keragaman yang berbeda pula baik dari segi bentuk, jenis, ukuran maupun jumlah spora. Hal ini menunjukkan bahwa keberadaan spora di lokasi areal revegetasi pascatambang pada site dan titik pengambilan sampel yang berbeda (Gambar 3). Pada site pertama jenis Acaulospora Sp.2 (87 Spora) memiliki jumlah paling tinggi ditemukannya pada sampel tanah dibandingkan dengan genus lainnya. Saputra et al., (2015) menyebutkan bahwa jenis Acaulospora salah satu spora yang bersifat spesifik dan memiliki adaptasi terbatas terhadap lingkungan. Genus Gigaspora lebih dominan dibandingkan genus Glomus diduga dikarenakan tekstur di lokasi penelitian adalah pasir berlempung. Kondisi tersebut sesuai dengan pernyataan Widiastutik dan Kramadibrata (1998) bahwa genus Gigaspora ditemukan dalam jumlah tinggi pada tanah bertekstur pasir, hal ini dikarenakan poripori tanah yang dimiliki tanah berpasir terbentuk lebih besar dibandingkan tanah lempung. Tanah bertekstur pasir mempunyai lebih banyak tekstur yang kasar dibandingkan tanah liat. Tanah dengan tekstur kasar akan sulit menahan air yang menyebabkan tanaman mudah mengalami kekeringan (Wedhana et al., 2018). Keadaan ini juga sesuai untuk perkembangan genus Gigaspora yang berukuran lebih besar daripada genus Glomus. Hasil identifikasi spora FMA pada lokasi areal revegetasi pascatambang tahun 2015 PT Natarang Mining yang ditemukan pada lokasi dapat dilihat pada Gambar 4. 


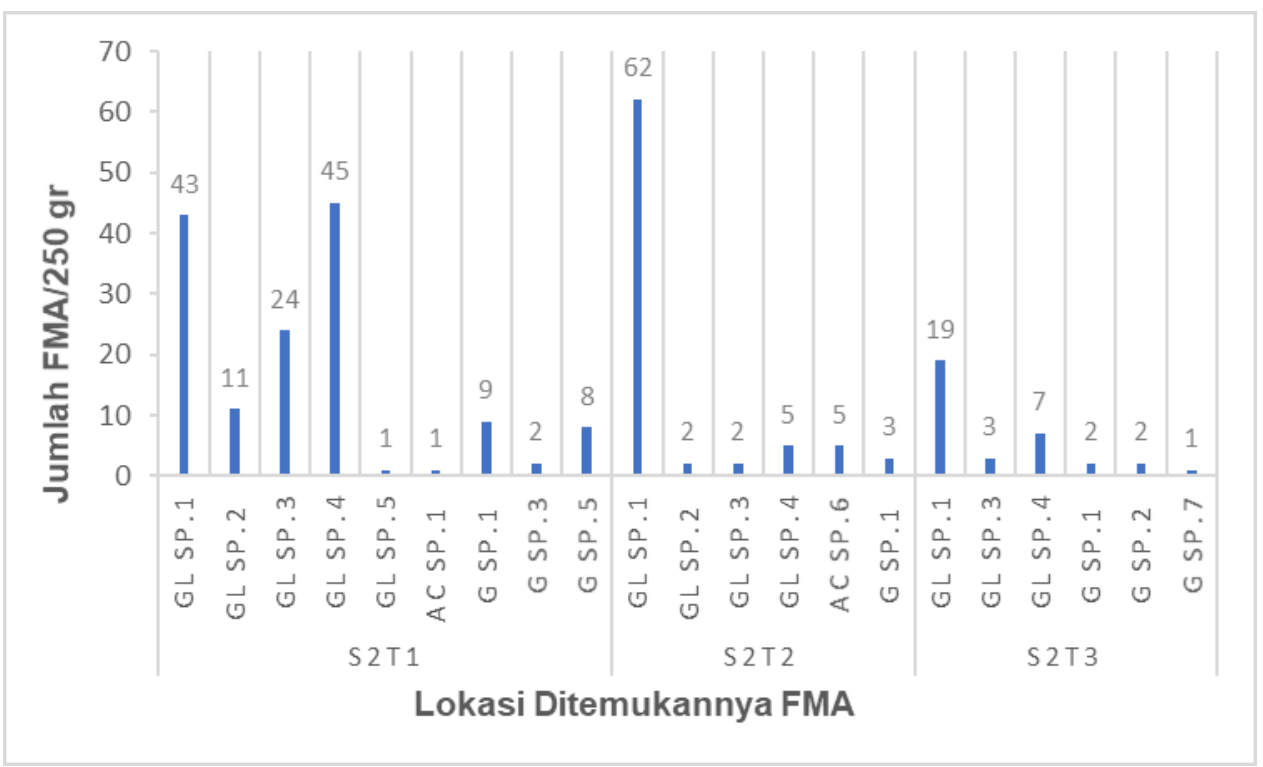

Gambar 4. Jenis-jenis spora yang ditemukan pada lokasi areal revegetasi pascatambang tahun 2015 PT Natarang Mining.

Figure 4. Types of spores found at the site of post-mining revegetation area in 2015 at PT Natarang Mining's.

Keterangan: S2T1 (Site 2 Titik ke-1), S2T2 (Site 2 Titik ke-2), S2T3 (Site 2 Titik ke-3), Gl (Glomus), Ac (Acaulospora), G (Gigaspora), dan sp. (Spesies).

Jenis mikoriza yang mendominasi lahan pascatambang pada lokasi ini, yaitu mikoriza genus Glomus sp.1 sebanyak 124 spora (Gambar 4), hal ini dikarenakan genus Glomus lebih tinggi penyebarannya jika dibandingkan dengan genus lainnya. Selain itu, kemampuan beradaptasi spora Glomus lebih baik dalam kondisi pH masam maupun netral (Sukmawaty et al., 2016). Margarettha (2011) juga menyebutkan bahwa genus Glomus merupakan tipe spora yang paling sering ditemukan baik pada tanah timbunan maupun tanah kupasan. Proses berkecambah spora mikoriza dari genus Glomus lebih cepat dibandingkan genus Gigaspora dan Acaulospora (Faiza et al., 2013). Dalam penelitian Faiza et al., (2013) tentang eksplorasi dan identifikasi mikoriza potensial pada lahan pascatambang batu bara diperoleh mikoriza genus Glomus Sp (9 tipe spora) yang lebih banyak dibandingkan spora mikoriza genus Acaulospora sp (3 tipe spora) dan Enthrospora sp (1 tipe spora). Tekstur tanah pada lokasi ini termasuk lempung hal ini yang tampaknya menyebabkan genus Glomus yang mendominasi. Hal ini sesuai dengan pernyataan Widiastutik dan Kramadibrata (1998) bahwa tanah yang didominasi oleh tekstur lempung cocok untuk perkembangan genus Glomus.

\section{Glomus sp}

Genus ini ditemukan pada kedua lokasi pengamatan pada site pertama tahun revegetasi 2018 (S1T1 dan S1T3) dan site kedua tahun revegetasi 2015 (S2T1, S2T2, dan S2T3) dengan jumlah spora yang beragam. Genus mikoriza glomus termasuk dalam family Glomaceae. Genus tersebut berwarna hyaline, kuning, merah kecoklatan, coklat dan hitam. Ciri khas genus Glomus terdapat sporogenus cell (SC) dan dinding spora yang tidak bereaksi apabila diberi larutan melzer's reagent. Jumlah dinding spora yang berlapis-lapis, tidak terdapat ornament dan adanya dudukan hifa yang lurus (Nusantara et al., 2012). Berdasarkan INVAM (2013) genus ini 
memiliki spresies paling banyak dibandingkan genus lainnya. Hasil pengamatan ditemukan beberapa jenis glomus dengan karakteristik yang berbeda dapat dilihat pada gambar 5 .

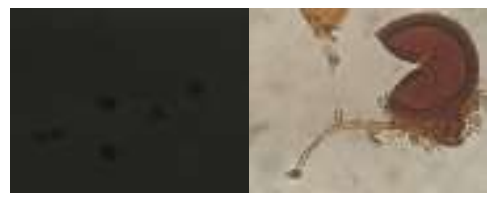

(a)

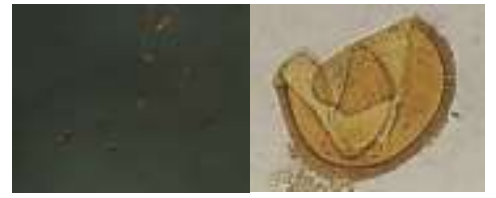

(c)

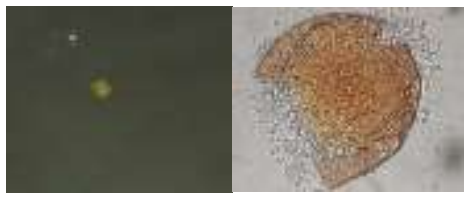

(e)

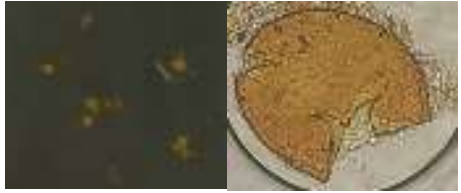

(b)

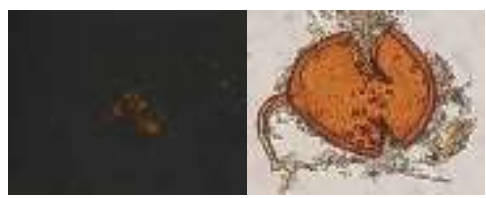

(d)

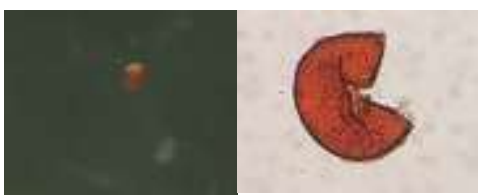

(f)

Gambar 5. Tipe spora glomus perbesaran 3,5 dan 400 kali, sebelum dan sesudah ditetesi larutan melzer's regeant. (a) Glomus Sp.1, (b) Glomus Sp.2, (c) Glomus Sp.3, (d) Glomus Sp.4, (e) Glomus Sp.5, dan (f) Glomus Sp.6.

Figure 5. Types of glomus spores with magnification of 3.5 and 400 times, before and after being dripped with melzer's regeant solution. (a) Glomus Sp.1, (b) Glomus Sp.2, (c) Glomus Sp.3, (d) Glomus Sp.4, (e) Glomus Sp.5, and (f) Glomus Sp.6.

\section{Acaulospora sp}

Genus Acaulospora sp di site pertama pada semua sampel tanah (S1T1, S1T2, dan S1T3), sedangkan pada site kedua ditemukan pada sampel tanah (S2T1 dan S2T2). Lapisan luar tidak bereaksi apabila diberi larutan melzer's regeant dan lapisan dalam akan bereaksi dengan menghasilkan warna lebih gelap-merah keunguan. Pada umumnya spora berukuran 100-200 mikron. Genus Acaulospora sp memiliki dinding yang tebal dan ornamen yang bergantung pada spesies nya. Dinding spora terdiri dari 2 lapisan di mana dinding bagian dalam terdapat germination orb. Berdasarkan INVAM (2013) warna spora yang dimiliki bervariasi mulai dari kuning, orange, kecoklatan merah tua hingga merah kecoklatan. Pengamatan Acaulospora $s p$ yang ditemukan dapat dilihat pada gambar 6 .

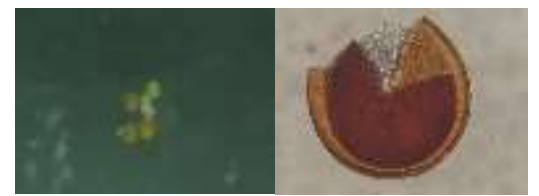

(a)

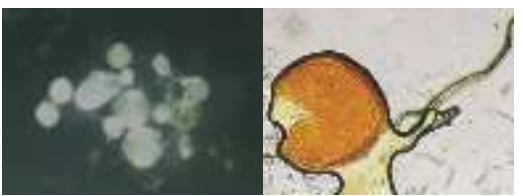

(b) 


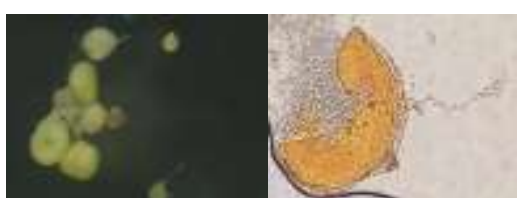

(c)

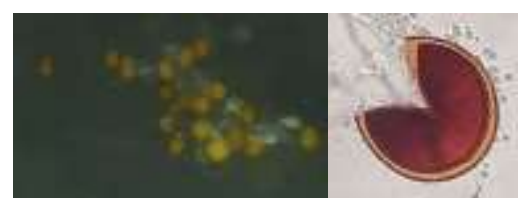

(d)

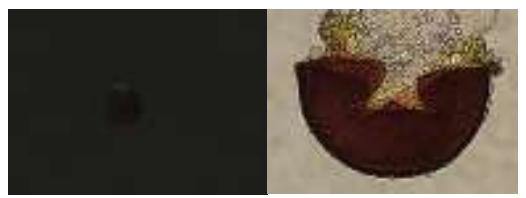

(e)

Gambar 6. Tipe spora glomus perbesaran 3,5 dan 400 kali, sebelum dan sesudah ditetesi larutan melzer's regeant. (a) Acaulospora Sp.1, (b) Acaulospora Sp.2, (c) Acaulospora Sp.3, (d) Acaulospora Sp.4, dan (e) Acaulospora Sp.5.

Figure 6. Types of glomus spores with magnification of 3.5 and 400 times, before and after being dripped with melzer's regeant solution. (a) Acaulospora Sp.1, (b) Acaulospora Sp.2, (c) Acaulospora Sp.3, (d) Acaulospora Sp.4, dan (e) Acaulospora Sp.5.

\section{Gigaspora sp}

Genus Gigaspora sp. termasuk dalam famili Gigaspraceae. Spora ini ditemukan pada semua sampel tanah baik pada site pertama (S1T1, S1T2, dan S1T3) maupun pada site kedua (S2T1, S2T2, dan S2T3) dengan jenis dan jumlah yang sedikit dibandingkan dengan jenis Glomus $S p$. Genus Gigaspora sp mempunyai bulbous suspensor tanpa germination sheld yang menjadi ciri khasnya (INVAM, 2009). Pada penelitian ini ada juga yang tidak memiliki bulbous suspensor atau sudah terlepas. Pada lapisan dinding spora yang tipis ( \pm 2 lapis) dan apabila diberi larutan melzer's regeant akan bereaksi secara menyeluruh. Spora genus ini memiliki bentuk globose. Spora yang ditemukan berwarna kuning, putih dan orange. Pengamatan Gigaspora yang ditemukan dapat dilihat pada gambar 7 .

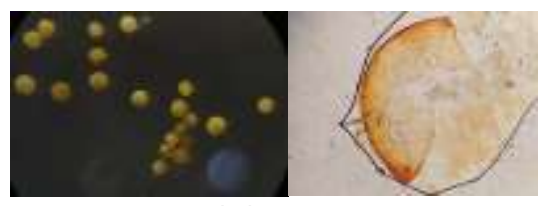

(a)

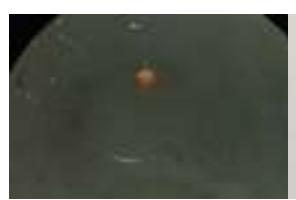

(c)

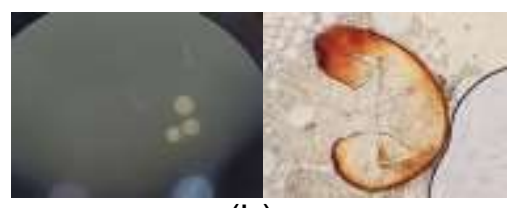

(b)

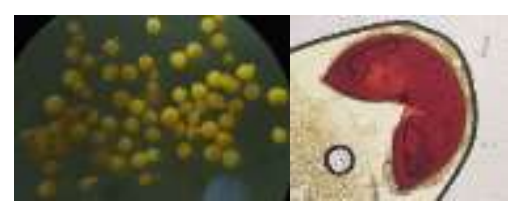

(d) 


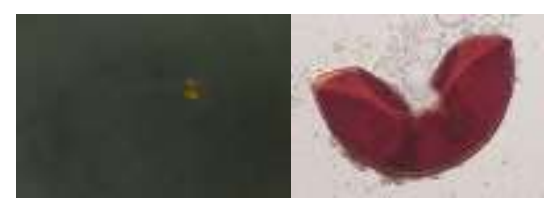

(e)

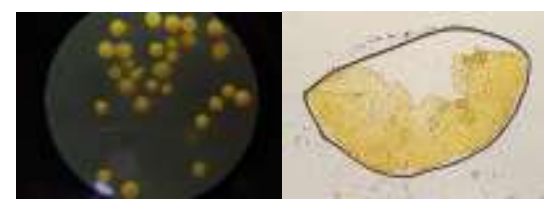

(g)

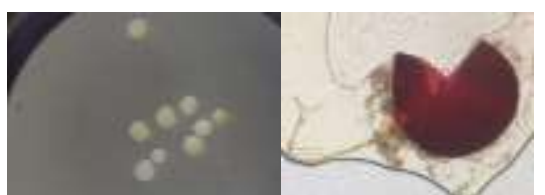

(f)

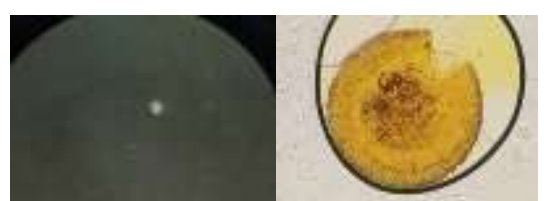

(h)

Gambar 7. Tipe spora glomus perbesaran 3,5 dan 200 kali, sebelum dan sesudah ditetesi larutan melzer's regeant. (a) Gigaspora Sp.1, (b) Gigaspora Sp.2, (c) Gigaspora Sp.3, (d) Gigaspora Sp.4, (e) Gigaspora Sp.5, (f) Gigaspora Sp.6, (g) Gigaspora Sp.7, dan (h) Gigaspora Sp.8.

Figure 7. Types of glomus spores with magnification of 3.5 and 200 times, before and after being dripped with melzer's regeant solution. (a) Gigaspora Sp.1, (b) Gigaspora Sp.2, (c) Gigaspora Sp.3, (d) Gigaspora Sp.4, (e) Gigaspora Sp.5, (f) Gigaspora Sp.6, (g) Gigaspora Sp.7, dan (h) Gigaspora Sp.8.

Pada umumnya spora terbentuk jika terjadi penurunan jumlah hara dari akar saat simbiosis FMA dan tanaman akan mengalami kematian (Asmarahman et al, 2018). Akar bagian yang berfungsi saat proses penyerapan unsur hara, air, dan zat terlarut di dalam tanah dan akan ditransferkan ke bagian tanaman yang membutuhkan (Krisdayani et al., 2020; Aji et al., 2020; Jayanti et al., 2019). Keanekaragaman spora dipengaruhi oleh faktor tanah (Saputra et al., 2015), sehingga pada penelitian ini juga dilakukan pengukuran analisis kimia tanah (Tabel 1). $\mathrm{pH}$ optimum untuk pertumbuhan FMA berkisar antara 4,0-6, walaupun setiap jenis FMA memiliki $\mathrm{pH}$ optimum berbeda untuk pertumbuhannya. $\mathrm{pH}$ tanah pada lokasi penelitian masih tergolong masam antara 4,0-4,5 (Tabel 1). Spora genus Glomus, Gigaspora, dan Acaulospora akan berkembang baik pada kisaran $\mathrm{pH}$ tersebut (Yusrinawati dan Sudantha, 2016). Hal ini juga berhubungan dengan ketersediaan unsur $\mathrm{P}$ karena umumnya tanah dengan kondisi asam atau pH dibawah 6,0 memiliki unsur hara $\mathrm{P}$ yang kurang (Sutedjo dan Kartasapoetra, 2005).

Tabel 2. Analisis sifat kimia tanah

Table 2. Soil chemical analysis

\begin{tabular}{|c|c|c|c|c|c|c|}
\hline \multirow{2}{*}{$\begin{array}{c}\text { Sifat Kimia } \\
\text { Tanah }\end{array}$} & \multicolumn{3}{|c|}{$\begin{array}{c}\text { Site-1 (Tahun Reklamasi } \\
\text { 2018) }\end{array}$} & \multicolumn{3}{|c|}{ Site- 2 (Tahun Reklamasi 2015) } \\
\hline & T1 & $\mathrm{T} 2$ & T3 & $\mathrm{T} 1$ & $\mathrm{~T} 2$ & T3 \\
\hline $\mathrm{pH}(\mathrm{H} 2 \mathrm{O})$ & 4,1 & 4,1 & 4,5 & 4,0 & 4,3 & 4,4 \\
\hline C-Organik (\%) & 0,26 & 0,25 & 0,42 & 1,99 & 1,65 & 2,0 \\
\hline N-Total (\%) & 0,02 & 0,03 & 0,04 & 0,23 & 0,19 & 0,25 \\
\hline C/N Rasio & 13 & 8 & 11 & 9 & 9 & 8 \\
\hline $\begin{array}{l}\text { P2O5 Tersedia } \\
(\mathrm{ppm})\end{array}$ & 7,0 & 2,2 & 5,7 & 2,0 & 3,6 & 5,6 \\
\hline
\end{tabular}

Keterangan: T1 (Titik pengambilan sampel tanah ke-1), T2 (Titik pengambilan sampel tanah ke2), T3 (Titik pengambilan sampel tanah ke-3), 
Kandungan C-Organik berkisar 0,25\%-2,0\% termasuk kategori sangat rendah hingga sedang berdasarkan standar baku kualitas tanah. C-Organik yang sedang pada lokasi penelitian, diduga terjadi akibat adanya proses pembentukan humus yang tahan terhadap dekomposisi serta waktu tinggal rata-rata C-Organik yang jauh lebih lama. Hal ini sesuai dengan penernyataan Sukarman dan Dariah (2014) bahwa humus akan terus terakumulasi seiring berjalannya waktu, sehingga membuat humus yang tahan terhadap proses dekomposisi. C-Organik yang tinggi di duga akibat adanya penumpukan serasah pohon yang berguguran diatas permukaan tanah dan terjadi proses dekomposisi sehingga menjadi pupuk organik (Thalib et al., 2021).

Analisis $\mathrm{N}$-total pada lokasi pengambilan sampel berkisar $0,02 \%-0,23 \%$ yang tergolong rendah hingga sedang. Nitrogen adalah unsur hara yang bermuatan positif $\left(\mathrm{NH}_{4}^{+}\right)$dan negatif $\left(\mathrm{NO}^{-}\right.$). Unsur hara nitrogen mudah hilang sehingga menjadi tidak tersedia bagi tanaman (Aji et al., 2018). Nilai $\mathrm{N}$-total yang sedang pada beberapa titik pengambilan sampel diduga dipengaruhi oleh C-Organik yang sedang juga. Keberadaan $\mathrm{N}$-total yang tinggi pada tanah apabila jumlah bahan organik juga tinggi yang disebabkan terjadinya proses dekomposisi. Hal ini searah dengan $\mathrm{C} / \mathrm{N}$ rasio yang dimiliki menunjukkan kualitas tanah tidak subur. Kualitas tanah yang tidak subur diketahui dari kandungan unsur hara P-Tersedia pada lokasi pengambilan sampel berkisar 2,0 ppm-7,0 ppm yang termasuk kedalam kriteria sangat rendah. P-tersedia yang rendah karena unsur $\mathrm{P}$ yang terfiksasi oleh $\mathrm{Al}$ dan $\mathrm{Fe}$ (Zurhalena dan Endriyani, 2004; Firmansyah et al., 2018). Selain itu, rendahnya kandungan unsur $P$ pada tanah dikarenakan oleh kondisi $\mathrm{pH}$ tanah yang masam (Riniarti dan Setiawan, 2014). Kekurangan Ptersedia akan mengurangi nitrogen dan mengakibatkan pertumbuhan tanaman terhambat (Sembiring, 2008). Rendahnya nilai C-Organik, N dan P menjadikan kondisi yang sangat sesuai untuk FMA dapat berkembang. Hal ini sesuai dengan pernyataan Adiaty et al., (2018) bahwa rendahnya kandungan unsur hara $P$ akan membantu mempercepat pertumbuhan hifa dari spora FMA yang telah berkecambah. Pemberian spora mikoriza mampu meningkatkan pertumbuhan tanaman (Handayani et al., 2018).

\section{KESIMPULAN DAN SARAN}

Jenis spora FMA yang ditemukan pada kedua lokasi areal revegetasi pascatambang emas PT Natarang Mining sebanyak 19 jenis FMA yaitu Glomus sp (6 tipe spora), Acaulospora sp (5 tipe spora), dan Gigaspora sp (8 tipe spora). Keanekaragaman jenis yang terdapat pada kedua lokasi sebesar 2,12 dan 1,57 dan nilai ini tergolong sedang. Penelitian lebih lanjut terkait identifikasi keankeragaman FMA lokal diharapkan mampu meningkatkan keberhasilan reklamasi. Identifikasi spora secara molekuler juga diperlukan untuk mengetahui spesies dan karakteristik spora dengan jelas.

\section{DAFTAR PUSTAKA}

Adiaty, T.O., Linda, R., \& Mukarlina. (2018). Jamur mikoriza vesikular vesikula arbuskular (mva) pada tiga jenis tanah rhizosfer tumbuhan lakum (Cayratia trifolia (L) Domi). Jurnal Protobiont, 7(3), 83-89.

Aji, I. M. L., Sutriono, R., \& Diansyah, A. (2020). pematahan dormansi benih aren (Arenga pinnata (Wurmb.) Merr.) pada tingkat kemasakan yang berbeda menggunakan metode perendaman. Jurnal Belantara, 3(1), 12-24. 
Aji, I. M. L., Sutriono, R., \& Hayati, M. (2018). Pengaruh media simpan dan lama penyimpanan terhadap viabilitas benih dan pertumbuhan semai mahoni (Swietenia Mahagoni (L.) Jacq). Jurnal Belantara, 1(1), 23-29

Anggreiny, Y., Nazip, K., \& Santri, D. J. (2017). Identifikasi fungi mikoriza arbuskula (fma) pada rhizosfir tanaman di kawasan revegetasi lahan penambangan timah di kecamatan merawang Kabupaten Bangka dan sumbangannya pada pembelajaran biologi sma. In Seminar Nasional Pendidikan IPA, 1(1), 391-403.

Asmarahman, C., Budi, S. W., Wahyudi, I., \& Santoso, E. (2018). Identifikasi mikroba potensial fungi mikoriza arbuskula (fma) pada lahan pascatambang PT. Holcim Indonesia tbk. Cibinong, Bogor, Jawa Barat. Jurnal Pengelolaan Sumberdaya Alam dan Lingkungan (Journal of Natural Resources and Environmental Management), 8(3), 279-285.

Brundrett, M., Bougher, N., Dell, T., Grove., \& Malajczuk. (1996). Working with mycorrhizas in forestry and agriculture. ACIAR Monograph 32.

Delvian. (2003). Keanekaragaman cendawan mikoriza arbuskula (cma) di hutan pantai dan potensi pemanfaatannya. Disertasi. Program Pascasarjana IPB Bogor.158p.

Ekawati, Mansur, I., \& Dewi, P. (2016). Pemanfaatan kompos dan mikoriza arbuscular pada longkida (Naculea orientalis) di tanah pascatambang nikel PT Antam Pomalaa. Jurnal Silvikultur Tropika, 7(1), 1-7.

Faiza, R., Rahayu, Y.S., \& Yulani. (2013). Identifikasi spora jamur Mikoriza Vesikular Arbuskula (MVA) pada tanah tercemar minyak bumi di Bojonegoro. Jurnal Lentera Bio, 2(1), 7-11.

Firmasnyah, A., Markum, M., \& Indriyatno, I. (2018). Pengaruh komposisi media tanam dan pemberian dosis pupuk pgpr (plant growth promoting rhizobacteria) terhadap pertumbuhan semai ketimunan (Gyrinops versteegii) cabutan. Jurnal Belantara, 1(1), 3034.

Hajoeningtijas, O. D. (2009). Ketergantungan tanaman terhadap mikoriza sebagai kajian potensi pupuk hayati mikoriza pada budidaya tanaman berkelanjutan. Agritech, 11(2), 125-136.

Handayani, I., Riniarti, M., \& Bintoro, A. (2018). Pengaruh dosis inokulum spora Scleroderma columnare terhadap kolonisasi ektomikoriza dan pertumbuhan semai damar mata kucing. Jurnal Sylva Lestari, 6(1), 9-15.

Hardiatmi, S. (2008). Pemanfaatan jasad renik mikoriza untuk memacu pertumbuhan tanaman hutan. Jurnal Inovasi Pertanian, 7(1), 1-10.

INVAM. (2009). International culture Collection of Vesicular Arbuscular Mycorrhizal Fungi. http: //invam.caf.WVH.Edu/Myco.Info/Taxonomi/Classification.htm. Diakses pada 21 Oktober 2020 Pukul 21.38.

INVAM. (2013). International Culture Collection of (Vesicular) Arbuscular Mychorrizal Fungi. http://invam.wvu.edu/the-fungi/classification. Diakses pada 04 April 2021 Pukul 20.45.

Jayanti, F. D., Duryat, \& Bintoro, A. (2019). Pengaruh pemberian ekstrak tauge dan bawang merah pada pertumbuhan bibit gaharu (Aquilaria malaccensis). Jurnal Belantara, 2(1), 7075.

Juliarti, A., Wijayanto, N., Mansur, I., \& Trikoesoemaningtyas. (2020). Analisis rendemen minyak serehwangi (Cymbopogon nardus L.) yang ditanam dengan pola Argoforestri dan monokultur pada lahan revegetasi pasca tambang batubara. Jurnal Sylva Lestari, 8(2), 181-188.

Karti, P. (2004). Pengaruh pemberian cendawan mikoriza arbuskula terhadap pertumbuhan dan produksi rumput setaria splendida stapf yang mengalami cekaman kekeringan. Jurnal Med.Pet, 27(2), 63-68.

Krisdayani, P.M., Proborini, M.W., \& Kriswiyanti, E. (2020). Pengaruh kombinasi pupuk hayati endomikoriza, Trichoderma spp., dan pupuk kompos terhadap pertumbuhan bibit sengon (Paraserianthes falcataria (L.) Nielsen). Jurnal Sylva Lestari, 8(3), 400-410. 
Lee, K.J., Lee, K.H., Tamolang, E.C., \& Budi, S.W. (2009). Biodiversity, spore density and root colonization of arbuscular mycorrhizal fungi at expressway cut-slopes in Korea. Jour Korean for Soc, 98(5),539-547.

Luthfiana, U., Riniarti, M., \& Bintoro, A. (2020). Aplikasi ektomikoriza (Scleroderma sp.) pada semai mangium (Acacia mangium Willd.) menggunakan media tailing pertambangan emas skala kecil. Jurnal Sylva Lestari, 8(1), 85-97.

Magurran, A.E. (2004). Measuring Biological Diversity. Malden:Blackwell Publishing.

Manaroinsong, E. \& Lolong, A.A. (2015). Identifikasi Cendawan Mikoriza Arbuskular (CMA) pada beberapa tekstur tanah di lahan kelapa sawit di Kalimantan Tengah. Balai Penelitian Tanaman Palma. 16(2), 203-210.

Margarettha. (2011). Eksplorasi dan identifikasi mikoriza indigen asal tanah bekas tambang batu bara. Jurnal Berita Biologi, 10(5), 641-647

Novera, Y. (2008). Analisis vegetasi, karakteristik tanah dan kolonisasi fungi mikoriza arbuskula (FMA) pada lahan bekas tambang timah di pulau Bangka. Tesis. Program Pascasarjana Institut Pertanian Bogor. Bogor.

Nusantara, A.D., Bertham, Y.H., dan Mansur, I. (2012). Bekerja dengan Fungi Mikoriza Arbuskula. Buku. Bogor: Seameo Biotrop.

Pacioni, G. (1992). Wet sieving and decanting techniques for the extraction of spores of VA mycorrhyzal fungi. Methods in Microbiology. Academic Press Inc. San Diego, 24, 317-322.

Pratomo, J. A., Banuwa, I. S., \& Yuwono, S. B. (2018). Evaluasi keberhasilan tanaman reboisasi pada lahan kompensasi pertambangan emas PT. Natarang Mining. Jurnal Sylva Lestari, 6(2), 41-50.

PT Natarang Mining. (2018). Adendum Andal RKL-RPL kegiatan pertambangan emas DMP Blok Way Linggo dan Blok Talang Santo (perubahan metode pertambangan dari underground menjadi open pit mine. Dokumen perusahaan. $617 \mathrm{p}$.

PT Natarang Mining. (2019). Rencana pascatambang PT Natarang Mining pertambangan emas dan mineral pengikutnya (DMP) Kabupaten Tanggamus, Lampung. Dokumen Perusahaan. 345p.

Rainiyati. (2007). Status dan keanekaragaman cendawan mikoriza arbuskula (cma) pisang raja nangka dan potensi pemanfaatannya untuk peningkatan produksi pisang asal kultur jaringan di Kabupaten Merangin, Jambi. Disertasi. Sekolah Pascasarjana IPB, Bogor. $140 \mathrm{p}$.

Riniarti, M., \& Setiawan, A. (2014). Status kesuburan tanah pada dua tutupan lahan di Kesatuan Pengelolaan Hutan Lindung (KPHL) Batutegi Lampung. Jurnal Sylva Lestari, 2(2), 99-104.

Saputra, B., Linda, R., \& Lovadi, I. (2015). Jamur mikoriza vesikular vesikula arbuskular (mva) pada tiga jenis tanah rhizosfer tanaman pisang nipah (Musa paradisiaca L. var. nipah) di Kabupaten Pontianak. Jurnal Protobiont, 4(1), 160-169.

Sembiring, S. (2008). Sifat kima dan fisik tanah pada areal bekas tambang bauksit di Pulau Bintan Riau. Jurnal Info Hutan, 1(2),123-134.

Setiadi, Y., \& Setiawan, A. (2011). Studi status fungi mikoriza arbuskula di areal rehabilitas pasca penambangan nikel (studi kasus PT INCO Tbk. Orowako. Sulawesi Selatan). Jurnal Silvikultur Tropika, 3(1),8-95.

Simangunsong, S.A. (2006). Pengaruh Pemberian Berbagai mikoriza dan Pupuk Kandang Ayam Pada Tanaman Tembakau Deli Terhadap Serapan P dan Pertumbuhan di Tanah Inceptisol Sampali. Skripsi. Padang: Departemen Ilmu Tanah Fakultas Pertanian Universitas Sumatera Utara.

Sofyan, R. H., Wahjunie, E. D., \& Hidayat, Y. (2017). Karakterisasi fisik dan kelembaban tanah pada berbagai umur reklamasi lahan bekas tambang. Buletin Tanah dan Lahan, 1(1), 7278. 
Sukarman. K., \& Dariah, A. (2014). Tanah andosol di Indonesia karakteristik, potensi, kendala, dan pengelolaannya untuk pertanian. Bogor: Balai Besar Penelitian dan Pengembangan Sumberdaya Lahan Pertanian.

Sukmawaty, E., Hafsan, \& Asriani. (2016). Identifikasi cendawan mikoriza arbuskula dari perakaran tanaman pertanian. Jurnal Biogenesis, 4(1), 16-20.

Sutedjo, M.M., \& Kartasapoetra, A. G. (2005). Pengantar Ilmu Tanah. Jakarta: PT Rineka Cipta.

Szwedzicki, T. (2001). Program for mine closure. Journal of Mineral Resources Engineering, 3, 347-364.

Tarmedi, E. (2006). Keanekaragaman Cendawan Mikoriza Arbuskula di Hutan Sub Pegunungan Kamojang Jawa Barat. Skripsi. Program Studi Budidaya Hutan Fakultas Kehutanan Institut Pertanian Bogor.

Thalib, M., Baderan, D. W. K., \& Katili, A. S. (2021). Produksi dan laju dekomposisi serasah Ceriops tagal di Cagar Alam Tanjung Panjang (the production and decomposition rate of Ceriops tagal Litter in Tanjung Panjang nature reserve). Jurnal Sylva Lestari, 9(1), 151160.

Tuheteru, F. D., Husna, H., \& Arif, A. (2011). Respon pertumbuhan dan ketergantungan Albizzia saponaria (lour.) Miq terhadap inokulasi fungi mikoriza arbuskula lokal sulawesi tenggara pada media tanah pasca tambang nikel. Berita Biologi, 10(5), 605-611.

Wedhana, I. B., Idris, M. H., \& Silamon, R. F. (2018). Analisis pertumbuhan tanaman kayu putih (Melaleuca cajuputi sub sp. cajuputi) pada kawasan hutan lindung Dusun Malimbu dan Dusun Badung Resort Malimbu Kphl Rinjani Barat. Jurnal Belantara, 1(1), 35-44.

Widiastuti, H. (2006). Infektivitas dan efektivitas propagaul mikoriza arbuskula yang diisolasi dari beberapa rizosfer kelapa sawit. Agronomi, 10(1), 33-36.

Widiastutik, H. \& K. Kramadibrata. (1998). Fungi mikoriza bervesikula-arbuskula di beberapa tanah masam dari Jawa Barat. Jurnal Menara Perkebunan, 60(1), 9-19.

Widodo. (2011). Kajian pemanfaatan lahan bekas tambang skala kecil untuk pertanian. Jurnal Teknologi Mineral dan Batubara, 7(3),17-26.

Yusriadi, Pata'dungan, Y. S., \& Hasanah, U. (2018). Kepadatan dan keragaman spora fungi mikoriza arbuskula pada daerah perakaran beberapa tanaman pangan di lahan pertanian desa sidera. Jurnal Agroland, 25(1), 64-73.

Yusrinawati \& Sudantha, I.M. (2016). Peranan jamur mikoriza vesikula arbuskular (mva) dalam meningkatkan ketahanan kekeringan, ketahanan, penyakit pertumbuhan dan hasil pada tanaman bawang. Program Pascasarjana. Universitas Mataram.

Zurhalena \& Endriyani. (2004). Evaluasi status kesuburan tanah Andisol pada kebun kopi rakyat di Kabupaten Kerinci. Prosiding Seminar Nasional Hasil-Hasil Penelitian Kajian Teknologi Pertanian Spesifik. Universitas Jambi, Indonesia. 